\title{
Duncan Kennedy on Constitutional Theory and Palestine
}

\begin{abstract}
Nimer Sultany
In this brief contribution I would like to acknowledge Duncan Kennedy's influence on my thinking and work in the past years. My own work has focused on constitutional law and theory-and although this was not a primary concern of Duncan's scholarshipin this piece I will focus on two aspects of his work and career that influenced me as his student, political ally, and friend: radical left theoretical thought and radical left practice. Indeed, this combination is the reason why many of us admire him. He is one of the few scholars who were able to commit in his long career to both projects: intellectual critique and a left-wing politics. He was able to prevent the stifling of critique by the political, and at the same time to perform critique without undermining the political. He did not fall to the trap of either the free-floating intellectual or that of the simple party member.
\end{abstract}

\section{From Private Law to Public Law}

As noted, constitutional law and theory were not a primary focus for Duncan, given the emphasis in his teaching and writing career on exposing the seemingly neutral, apolitical, and technical language of private law arrangements that structure the background conditions to societal arrangements. Building on and extending the work of the American legal realists who came before him, Duncan sought to expose the 'unfreedom' that permeates the supposedly private sphere of autonomous individuals who can form their choices within the shield of individual rights. These arrangements are not merely coercive; they have distributive outcomes-they produce winners and losers-and some of these outcomes may well be politically objectionable.'

This is part of his larger theoretical endeavor of critique of liberal legalism. ${ }^{2}$ There is no rational defense of the belief in liberal legality as a primary tool of advancing society towards liberal or progressive goals. The "law", according to Duncan, cannot be explained in a systemic way-neither doctrinally nor indeed normatively. It cannot be theorized as perfectly complete and coherent: it includes gaps (previously unforeseen by the jurists), ambiguities (abstract terms) and contradictions (between different parts of the body of legal materials). Even more importantly than their mere existence, these gaps, conflicts and ambiguities create the possibility of manipulation of legal arrangements, manipulation that can be accomplished by both progressives and conservatives. There is no reason to think that manipulation will serve only the goals of progressive justice. It may. But it may not.

Moreover, the law cannot be explained exclusively from an internal perspective because the law is intertwined with politics and ideology. It is not a closed moral system. Rather, political and ideological orientations influence legal regulation and

' See, e.g., Duncan Kennedy, The Stakes of Law, or Hale and Foucault!, 15 LEGAL STUDIES

${ }^{2}$ Duncan Kennedy, A Critique of Adjudication (Fin de siècle) (1997). 
interpretation. The law is a site for political contestation and as such its evolution cannot be explained without recourse to seemingly "external factors." In return, law constitutes social relations and consciousness.

\section{From the Fundamental Contradiction to Loopification}

Duncan's primary article on constitutional law is one of an atheist outlook: the "People" who created the constitution is a fictitious entity that does not correspond to empirical and rationally verified realities. It is the outlook of an outsider who mocks the constitutional lawyers' faith in constitutional law as a moral repository of the American people. ${ }^{3}$ Nevertheless, he credits conservative constitutionalism with forcing the progressives towards demystifying legal reasoning: this made legal realism possible which eventually paved the way to critical legal studies."

In many ways, my work to date has consisted in applying or expanding Duncan's insights more directly into constitutional theory. Like him, I approached US constitutional debates from the perspective of the outsider who seeks to map the debates rather than be part of them. Specifically, his method and his main insight in "The Structure of Blackstone's Commentaries" served as a model that inspired some of the lines of inquiry that I pursued in my dissertation. ${ }^{5}$ That was not my original plan. However, my eclectic theoretical intervention ended up similar to his eclectic theoretical standpoint. And his articles on private law ended up influencing my thinking on public law and theory.

Duncan's methods combined structural mapping and post-structural deconstruction. These methods are fruitful and insightful for students of constitutional law and theory. Like "The Structure of Blackstone's Commentaries" one can highlight a discursive structure underlying the primary debates in constitutional theory. Additionally, this methodological exercise leads to similar conclusions. Duncan affirms a fundamental contradiction between altruism/community and selfishness/individualism. Likewise, the foundational paradox in political and constitutional theory between democracy and constitutionalism is irreconcilable. Crucially, for Duncan this paradox is not only external but also to us. No wonder then that the political systems we construct are embedded with these contradictory orientations.

However, recognition of this irreconcilability is not forthcoming. The reason for that is what Duncan calls-in his deconstructive mode-"loopification.” This is a category he used primarily in two of his well-known articles: "The Stages of the Decline of the

\footnotetext{
${ }^{3}$ Duncan Kennedy, American Constitutionalism as a Civil Religion: Notes of an Atheist, 19 Nova L. REV. 909 (1995).

${ }^{4} I d$. at 921 .

${ }^{5}$ Duncan Kennedy, The Structure of Blackstone's Commentaries, 28 BUfF. L. REv. 205 (1978).

${ }^{6}$ Nimer Sultany, The State of Progressive Constitutional Theory: The Paradox of Constitutional Democracy and the Project of Political Justification, 47 HARV. C.R.-C.L. L. REv. 371 (2012).
} 
Public/Private Distinction" ${ }^{17}$ and "Freedom and Constraint. ${ }^{18}$ Loopification shows that debates that look polarized are actually "circular." They are circular because the participants in the debate move around the foundational tension that gives rise to the debate in the first place rather than directly face it. They defend one side of the debate by deducing their preferred concept from the other competing concept. In other words, rather than acknowledging the paradox they solve it through definitional fiats. In a sense, they are cheating: the reason for the debate is that there is a tension between two opposing concepts. Their solution is to collapse the distinction. This is true of the public/private opposition as much as of the democracy/constitutionalism opposition.

There are many consequences that such a critical method highlights. First, these are for the most part abstract conceptualist debates that push aside a serious consequentalist and pragmatic assessment of real world consequences. A debate that is supposed to emerge from a concern about institutional structures ends up being a professionalized, philosophical debate-as Duncan warned. ${ }^{10}$ Ultimately, abstract solutions do not determine concrete arrangements. This critique of formalism is a persistent theme in legal realism and critical legal studies."

Secondly, there is what Duncan calls the "apologetic aspect of legal thought." ${ }^{12}$ The rights consciousness mediates our contradictory values and impulses. Indeed, providing solutions to apparent paradoxes serve an ideological role; their psychological and political effects are to quiet our anxiety about the social and political systems that regulate our lives. If once and for all, it can be shown that there is no paradox, or that it can be solved through minor reforms, then there is no need to worry about it. ${ }^{13}$

Unlike initial reactions to Duncan's thesis on the fundamental contradiction-which famously led Duncan to renounce it ${ }^{14}$ the point is to worry constantly about contradictions and keep them in mind. There is no a priori solution for them. There is no one size fits all. There is a need to experiment. This is part of the (anti-formalist) pragmatic spirit. Identifying the contradiction is not an excuse for doing nothing. It is a call for constant critical examination of perceived truths, common sense, and the status quo. ${ }^{15}$

${ }^{7}$ Duncan Kennedy, The Stages of the Decline of the Public/Private Distinction, 130 U. PENN. L. REV. 1394 (1982).

${ }^{8}$ Duncan Kennedy, Freedom and Constraint: A Critical Phenomenology, in LEGAL REASONING: COLLECTED ESSAYS (2008).

${ }^{9}$ Sultany, supra note 6 .

${ }^{10}$ KenNedy, supra note 2, at 50.

"Duncan Kennedy, Legal Formalism, in Neil J. Smelser \& Paul B. Baltes (eds.), 13 ENCYCLOPEDIA OF THE SOCIAL \& BEHAVIORAL SCIENCES 8634 (2001).

${ }^{12}$ Kennedy, The Structure, supra note 5, at 217.

${ }^{13}$ Sultany, supra note 6 .

${ }^{14}$ Duncan Kennedy \& Peter Gabel, Roll Over Beethoven, 36 STAN. L. REv. 1 (1984).

${ }^{15}$ See, e.g., a utilization of Kennedy's argument to examine bureaucratic structures and reject their legitimation administrative and corporate law, in Gerald E. Frug, The Ideology of Bureaucracy in American Law, 97 HARV. L. REV. 1276 (1984). 
Likewise, the point of highlighting potential indeterminacy in legal regulation and reasoning-and hence disenchantment with the law-is not to justify lack of resistance. ${ }^{16}$ Rather, it urges the social agent to be reflective in approaching legal venues and maintain a critical distance. It moves the attention from the legal materials to the "work" of the "agent." It makes the agent realistic about her chances to stabilize or destabilize legal meanings and arrangements. Ignoring these lessons may be detrimental to the social agent's cause. Ignoring indeterminacy, contingency and complexity might be "empowering" but also often illusory.

\section{Duncan's activism: Iraq, Palestine, Occupy!}

Duncan's theoretical insights on the indeterminacy of the rights discourse and the limits and pitfalls of adjudication are useful in contexts like Palestine. ${ }^{17}$ But Duncan's political contributions were not limited to academic discussions. Duncan never shied away from controversy and political debate. In a recent article in Transnational Legal Theory Duncan reflects on his ability to combine both. ${ }^{18}$

A primary example of his activism is, of course, the war on Iraq. Expressing his opposition to the war, he wrote an early op-ed, ${ }^{19}$ and then a journal article. ${ }^{20} \mathrm{He}$ also led the conference we the students organized on March 2008-"Confronting Empire: Five Years of War on Iraq."

But I would like to focus here on my own impressions of his activism during my stay at Harvard Law School. In one of my earliest meetings with Duncan in 2006, we discussed the student group Justice for Palestine at HLS. He had already been serving as the faculty advisor to the group since its inception more than four years earlier. Amazingly, Duncan told me (roughly): "Use me in any way you want. I have no ego in this. If you need a speaker, a moderator, etc." ${ }^{22}$ Needless to say, this approach was inspiring to me. About eight years later, when I am now a lecturer, I tried to imitate Duncan and said something similar to students in my home institution. For some reason it did not have the same authoritative effect!

Indeed, Duncan's willingness to be mobilized in order to educate people about Palestine and Israeli practices within and without Harvard was remarkable. This

\footnotetext{
${ }^{16}$ For the argument that "totalized indeterminacy" is "disarming" and leads to "paralysis," see Christopher Tomlins, What is Left of the Law and Society Paradigm after Critique? Revisiting Gordon's “Critical Legal Histories”, 37 L. \& Soc. INQ. 155, 164 (2012).

${ }^{17}$ Nimer Sultany, Activism and Legitimation in Israel's Jurisprudence of Occupation, 23 SoC. \& LEG. STUD. 315 (2014).

${ }^{18}$ Duncan Kennedy, Left Theory and Left Practice: A Memoir in the Form of a Speech, 5 Transnat'L Legal TheORY 577 (2014).

${ }^{19}$ Duncan Kennedy, Rationalizing War, Al-Ahram Weekly, May 8, 2003.

${ }^{20}$ Duncan Kennedy, Iraq: The Case for Losing, 31 Brook. J. InT'L L. 1 (2006).

${ }^{21}$ See http://hlsjusticeforpalestine.blogspot.co.uk/2008/03/confronting-empire-five-years-of-warin_10.html.

${ }^{22}$ It turns out that this is an approach that Duncan long adopted with other marginalized groups with a just cause. See Kennedy, supra note 18.
} 
involved teaching a new (initially controversial) course: Israel/ Palestine: Legal Issues. ${ }^{23}$ He spoke at numerous events and conferences that we organized, participated in quasiannual debates with Noah Feldman on US foreign policy, Iraq, and Israel/ Palestine. He hosted "controversial" speakers like Norman Finkelstein, wrote op-eds in the Harvard Crimson, ${ }^{24}$ gave interviews to the media, spoke to students at a private high school in the MA area on Palestine, signed an open letter to Harvard President and the dean of the Kennedy School of Government protesting the fact that they distanced themselves from a student conference on the One State solution, ${ }^{25}$ and on and on and on.

This meant that Duncan exposed himself to risks. Expressing critical views on Israel, supporting the Palestinian cause (and critiquing US complicity) is not a risk-free business in the US generally and Harvard in particular. A far right wing and Zionist student set up a blog critiquing every single class in the first year of the course Israel/ Palestine: Legal Issues. Vicious op-eds in the Crimson attacked Duncan. ${ }^{26}$ Senator Scott Brown (MA) and many others publicly criticized the One State conference. ${ }^{27}$ And, eventually (though predictably) Duncan came under fire from his HLS colleague Alan Dershowtiz in $2010 .^{28}$ No wonder that few professors were willing to speak up on this issue and support us.

Yet, Duncan contributed to the shift in public debate on Israel/Palestine in the US. His influence went beyond the students he taught in Legal Issues. His website provided online and free access to the course syllabus and reading materials. The first two years of the course in particular witnessed an impressive number of downloads. Other teachers took the course to other schools.

Moreover, we witnessed through the years an increase in turnout to our events. In 2006 the average turnout was roughly 25 students. By 2012, we had events with 200300 attendees. A fourth in a series of debates between Feldman and Kennedy,

\footnotetext{
${ }^{23}$ See Duncan Kennedy, Israel/Palestine Legal Issues: Course Summary, available at http://duncankennedy.net/teaching\%20materials/Is-Pal/summary.html.

${ }^{24}$ Duncan Kennedy, A Context for Gaza, The Harvard Crimson, Feb. 2, 2009.

${ }^{25}$ Duncan Kennedy et al., Open Letter to Harvard President: Charges that one-state conference is anti-semitic are 'defamatory' and serve 'to prevent rational discussion of ideas,' MONDOwEISs, Feb. 27, 2012, available at http://mondoweiss.net/2012/02/open-letter-toharvard-president-charges-that-one-state-conference-is-anti-semitic-are-defamatory-and-serve-toprevent-rational-discussion-of-ideas.

${ }^{26}$ See, e.g., Joel B. Pollak, Tenured but Wrong, The Harvard Crimson, Feb. 4, 2009; Julia I. Bertlesmann, Who's Really Trembling?, The Harvard Crimson, Nov. 28, 2007.

${ }^{27}$ Noah Bierman, Scott Brown calls on Harvard to cancel 'one state' conference, THE BosTON GLOBE, Mar. 2, 2012.

${ }^{28}$ See Phillip Weiss, Dersh the knife, Mondoweiss, May 13, 2010, available at http://mondoweiss.net/2010/05/dersh-the-knife; Phillip Weiss, Dershowitz expects to teach another professor's class, MONDOwEISs, May 14, 2010, available at http://mondoweiss.net/2010/05/dershowitz-has-groucho-marx-syndrome-only-wanting-to-be-atevents-that-dont-invite-him.
} 
moderated by Frank Michelman, on "Can Israel be both Jewish and Democratic?" attracted a full-capacity Ames Courtroom. ${ }^{29}$

Duncan's positions on Iraq and Palestine were part of his general radical left position. In 2011, I was fortunate to march side by side with Duncan (along with my friend Goncalo de Almeida Ribiero and others) in an Occupy Boston march. This march was an offshoot of the Occupy Wall Street marches that swept through US cities in the wake of the Arab Spring. Duncan was delighted to see the new generation of leftwing protestors driven by ideals of participatory democracy, equality and justice. It seemed he was happy to witness new torch-bearers. Earlier, he had defended the Occupy Harvard students, who camped at the Harvard yard, against university restrictions. ${ }^{30}$ This was consistent with Duncan's practice of championing student activism. Three decades earlier, in 1986, Duncan supported other students who occupied the Harvard yard: activists for divestment against the South African apartheid. ${ }^{31}$

\section{The Academic Oppositionist}

This is all to say that Duncan's intellectual courage is matched by his political courage. He founded critical legal studies at the time it was an iconoclastic project in the US legal academia. And he remained faithful to his radical insights and methods at the time many of his former fellow travelers moved to the center of the political map or to newer academic fashions. Likewise, he defended the Palestinian cause when few others did in a conservative milieu that prized political correctness and shied away from polemics. He is a genuine model for the scholar-activist.

Duncan has theorized this unison of academia and activism in his unpublished piece "Notes of an Oppositionist in Academic Politics. ${ }^{\text {"2 } 2}$ Written in December 1980, Duncan gives an initial formulation of the theoretical and even programmatic foundations of his actual practice. In an email Duncan told me that the title of this paper "refers to the opposition to Stalin inside the Soviet Communist Party during his consolidation of power by liquidating his enemies." ${ }^{33}$ Duncan defines an academic oppositionist as someone who speaks off the wall and who believes in the revolutionary potential in everyone. ${ }^{34}$ Unlike the academic eccentric, the oppositionist's goal is to

\footnotetext{
${ }^{29}$ Noah Feldman \& Duncan Kennedy Debate Can Israel Be Both Jewish and Democratic, available at https://www.youtube.com/watch? $\mathrm{v}=\mathrm{UMBr} 4 \mathrm{QFLelw}$.

${ }^{30}$ Brad Johnson, Harvard Law Professor Criticizes 'Homeland Security Feel' Of 'Overreaction' To Occupy Harvard, Think Progress (Nov. 12, 2011).

${ }^{31}$ See, e.g., Rediet T. Abebe \& Julia L. Ryan, Protesting Apartheid, The Harvard Crimson, May 25, 2011.

${ }^{32}$ Duncan Kennedy, Notes of an Oppositionist in Academic Politics (unpublished, Dec. 1980). Duncan gave me a copy of this paper some years ago. The 25-page copy was printed in 1982 .

${ }^{33}$ Email from Duncan Kennedy to Nimer Sultany, 15 September 2015.

${ }^{34}$ Kennedy, supra note 32, at 7, 13.
} 
mobilize others effectively. He or she is engaged in a learning process of experimentation and modification. ${ }^{35}$

The benefits of speaking off the wall according to Duncan: ${ }^{36}$ First, to retain selfrespect through the courage to voice one's opinions and question the premises of the conversation, notwithstanding the fear from others' disapproval. Silence is a betrayal of one's self and a march towards opportunism; second, to persuade others to join the cause and to change the boundaries of the conversation; third, to facilitate the emergence of a left faction. This, of course, requires tactical considerations on how to present one's views.

Finally, Duncan argues that once one engages in an oppositionist practice, one discovers "how little they can do to you. ${ }^{{ }^{37}}$ Certainly, Duncan's experience in voicing controversial views inside and outside academia confirms that.

Never fear-Duncan will be there for the next demonstration. Will you be there too, dear reader?

${ }^{35} I$ d. at $14-17$.

${ }^{36} I d$. at $8-12$.

${ }^{37} I d$. at $17-18$. 